\title{
Editorial
}

This issue of the Journal of Belarusian Studies explores the little-known historical connections between Belarus and Denmark, the fate of the Jewish population in Brest-Litovsk during the First World War, the history of the Francis Skaryna Belarusian Library and Museum in London and how textile ornaments visualize Belarusian cultural identity. The inclusion of a significant number of illustrations, both historical and contemporary, give a better sense of the historical processes examined in the articles and make for a departure from the journal's usual content.

In the first article, Lizaveta Dubinka-Hushcha from Denmark compares two national shrines, the Cross of Dagmar (Denmark) and the Cross of St. Euphrosyne (Belarus), providing novel evidence that both crosses could have been made by the same master. According to one theory, the Cross of Dagmar could have come to Denmark together with Queen Sophia via Minsk, Belarus. The purpose of the article is to verify this hypothesis, combining Belarusian and Danish sources for the first time. Dr Dubinka-Hushcha demonstrates that the Belarusian principalities maintained strong historical connections with Denmark and the marriage of Sophia, a daughter of Volodar of Minsk and Richiza of Poland, to King Valdemar of Denmark established a permanent practice. For the next five centuries Danish kings only married foreigners. The article includes high quality illustrations, including photos of the Cross of Dagmar and the Cross of St. Euphrosyne.

In the second article, Boris Czerny (France) and Efim Basin (Belarus) analyse the circumstances in which the Jewish population of the Belarusian city of Brest (then known as Brest-Litovsk) found itself between 1915 and 1919. The article results from an examination of unpublished documents and an account of events in the Yiddish language. They demonstrate that, contrary to some earlier publications on Brest-Litovsk, the Jewish population did not totally disappear from the city and its surroundings. The authors offer a micro-historical perspective on the population of Brest-Litovsk through an examination of passports, certificates and other personal documents; they shift focus from the population studies more typical in the historiography to specific individuals. The article reveals statistical data, maps as well as images of original personal documents from the period. 
Arnold McMillin offers his perspective on one of the key institutions of the Belarusian diaspora-the Francis Skaryna Library and Museum in London. The author recalls the origins of the library in 1971 to its current state. The publication shows the role of Belarusian priests, British scholars and other enthusiasts of Belarusian culture and literature in shaping the library's mission and activities. The article touches upon its rich collection of books (old and new), journals, manuscripts, music and other artefacts. He notes that the establishment of the library made the Belarusians the pioneers among other diasporas in their efforts to establish a cultural centre in the United Kingdom after the Second World War.

Professor McMillin's own scholarly achievements were to a significant extent based on the library's resources, ranging from his first monograph published in 1973 to nearly twenty publications in the Journal of Belarusian Studies. Professor McMillin describes the golden age of the library from its opening in new premises to the death of Fr. Alexander. During this period the library saw an exponential rise in the number of books, periodicals and archive materials acquired, many due to work performed in North America, as well as the support of Belarusian communities in the north of England. The article also briefly touches upon the history of the Journal of Belarusian Studies which was first published under the auspices of the Anglo-Belarusian Society in 1965 .

A.M. LaVey from the University of Rhode Island in the United States examines the evolving semiosis of Belarusian textiles. He tracks how the traditional embroidered ornament has evolved from a talisman into ubiquity and highlights the evolving statements textiles make within contemporary Belarusian culture. His article focuses on the use of textiles in the months surrounding the 2020 presidential election and the large-scale protests which followed. The article, with six accompanying illustrations of garments with embroidered ornament, brings to light how textiles continue to be symbols and visual expressions of Belarusian cultural identity. It draws on both primary and secondary sources to demonstrate the entwined historical connection of the Belarusian people to the textiles, which visually communicate different ideas of national identity, political beliefs and fashion.

The issue concludes with a book review prepared by Sofie Bedford from Uppsala University in Sweden. Anastasiya Astapova's book Humor and Rumor in the Post-Soviet Authoritarian State is based on ethnographic fieldwork in Belarus between 2011 and 2018. The book sheds light on questions such as why people in authoritarian regimes use humour despite the risk of punishment, and how they align with (or oppose) state policies and practices in nondemocratic regimes. Dr Bedford concludes that although the stories in the book are undeniably, at times, funny, what they tell us about the horror and 
surrealism characterising authoritarianism in contemporary Belarus is no laughing matter.

As previously, most articles published in the journal resulted from presentations at the Annual Conference on Belarusian Studies organised in 2021 by the Ostrogorski Centre, University College London and the Francis Skaryna Belarusian Library and Museum in London.

\section{Yarik Kryvoi}

Editor-in-Chief 